ارزيابى كارايى و آناليز حساسيت روش COP مبتنى بر تكنيك RS و GIS در تعيين

$$
\text { آسيبِيذيرى آبخوان كارستى دشت الشتر لرستان }
$$

حسين يوسفى "، على حقى زاده'، يزدان ياراحمدى' و بروين نورمحمدى'

(تاريخ دريافت: 1/199

جكيده

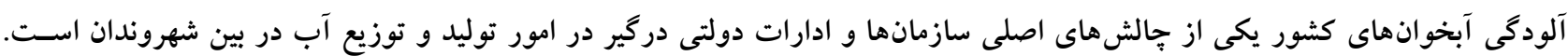

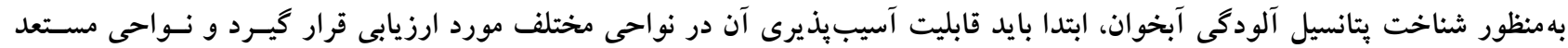

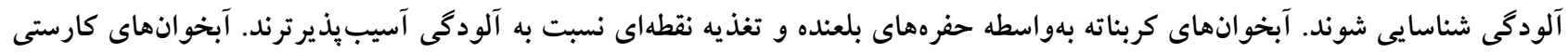

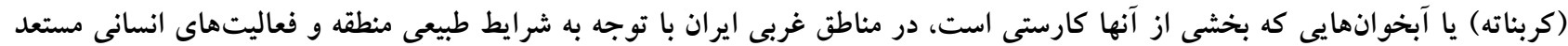

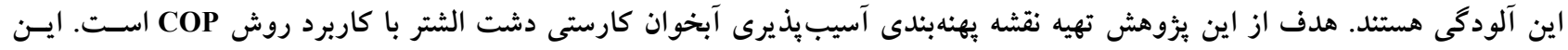

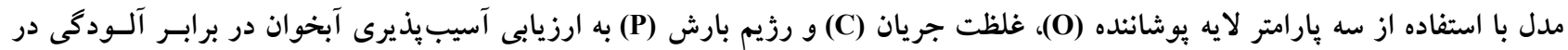

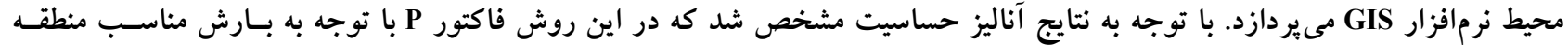

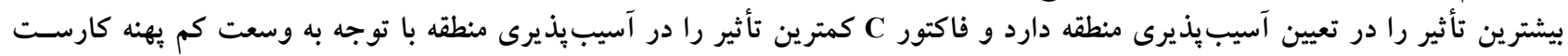

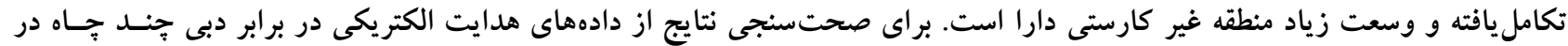

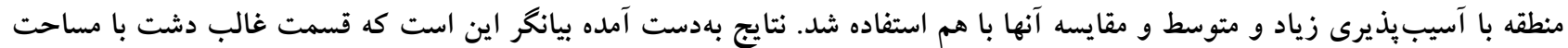
SV/V

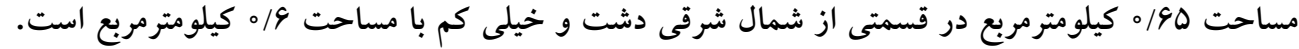

وازمهاى كليدى: آسيب يُيرى، روش COP، GIS، آبخوان كارستى دشت الشتر

ا. كروه انرزىهاى نو و محيط زيست، دانشكده علوم و فنون نوين، دانشخاه تهران

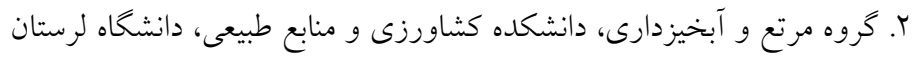

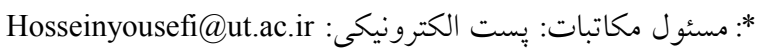


آسيبِيذيرى آبخوان شيمبا به روش COP بـا استفاده از GIS و و

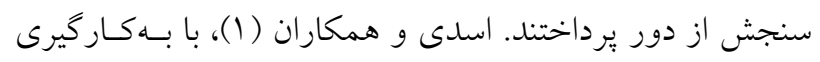

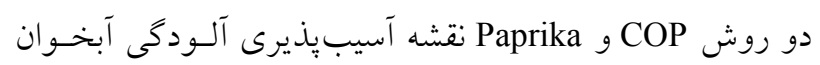

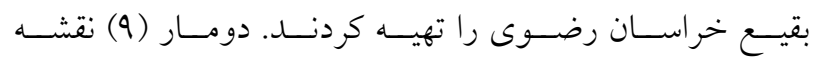

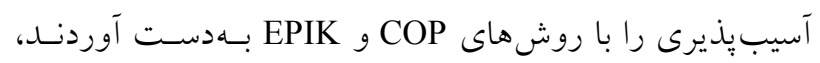
همجنين روش COP توسط ديميتريو و همكاران (ᄉ) در يونـان،

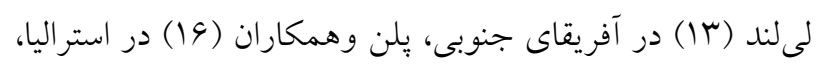

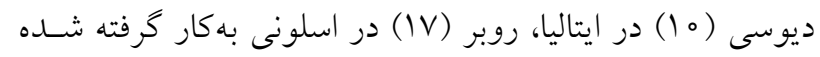

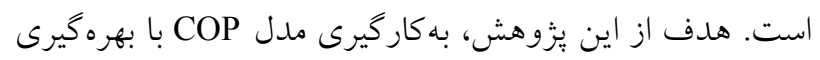
از سيستم اطلاعات جغرافيايى بهعنوان يكى روش مؤثر در تهيـهـ

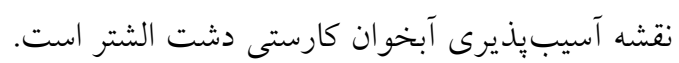

\section{مواد و روشها

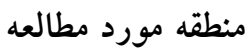

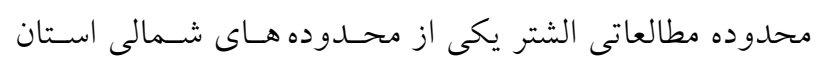

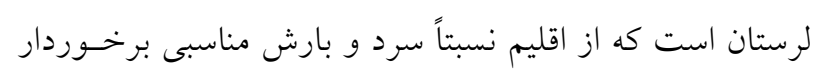

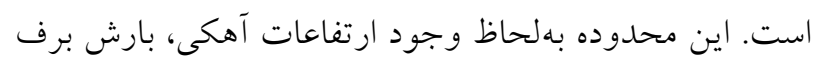

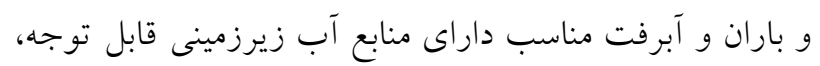

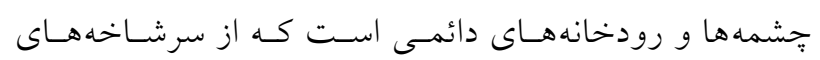

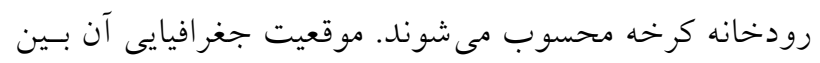

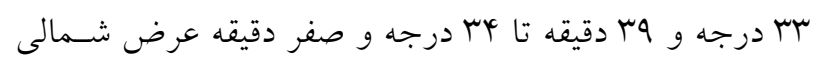

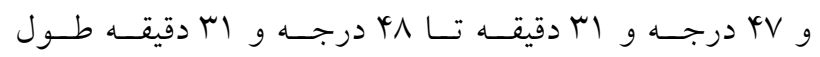

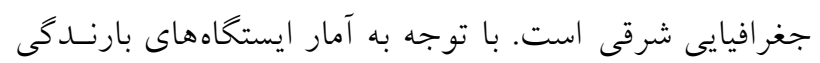

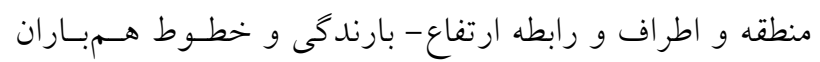

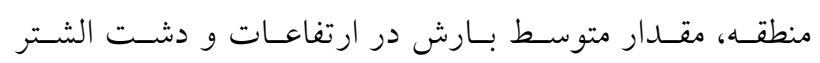

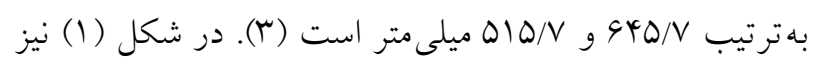
مى توان موقعيت دشت الشتر را در شهرسـتان، استسان و ايـران مشاهده كرد. - مرن.

ويزگ هاى زئومورفولوزى محدوده مطالعاتى الشتر

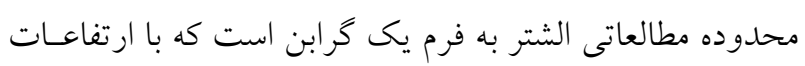

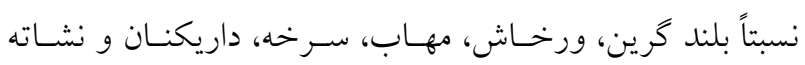

امكان نفوذ و انتشار آلايندهها به درون سيستم آب زيرزمينس را

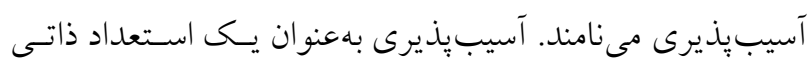

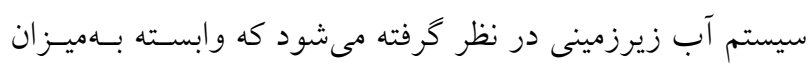
حساسيت اين سيستم به تأثيرات انسانى و يا طبيعى اسـت فئ. وربـا

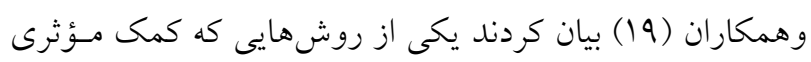

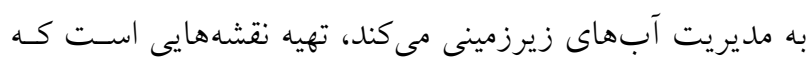

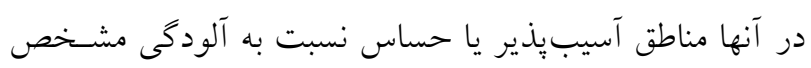

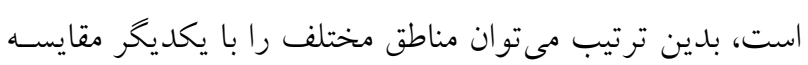
كرد و معيارى واحد جهت ارزيابى در اختيار داشت.

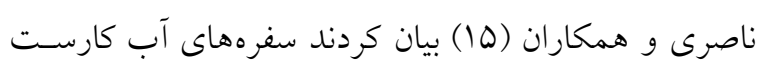

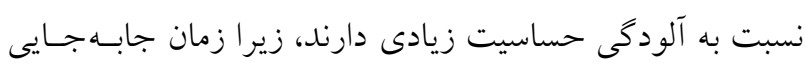

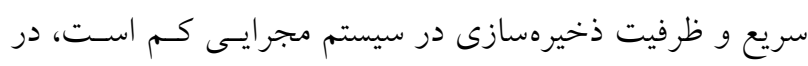

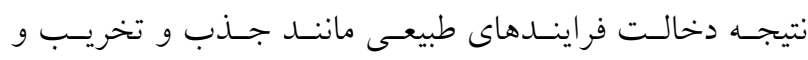

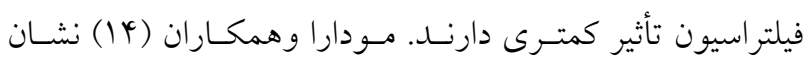

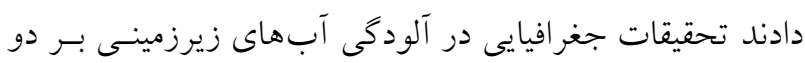

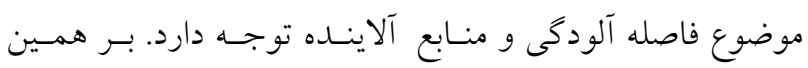

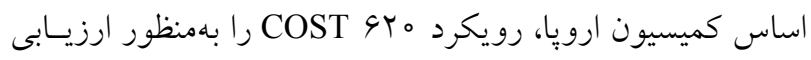
آسيب يذيرى و تهيه نقشه خطر منـابع آب كارسـت ارائسه كـرده

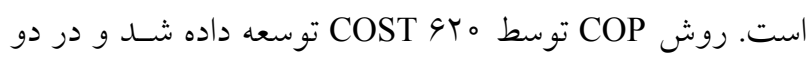

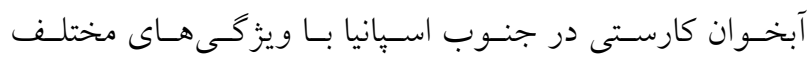
آبوهوايى و هيدرولوزيكى آزمايش و توسعه داده شد. در مدل آدل

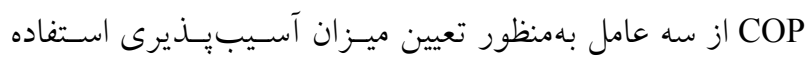

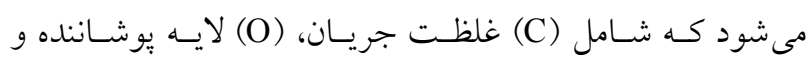

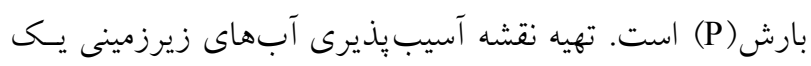

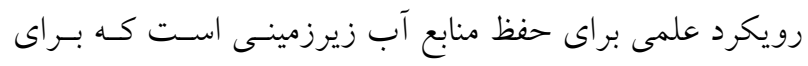

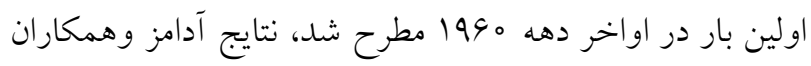

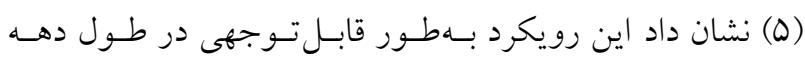

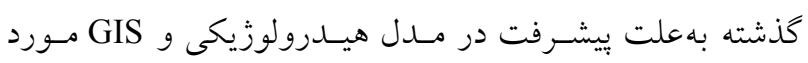

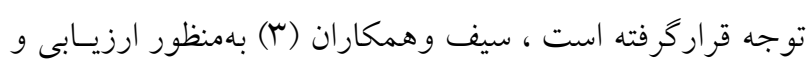

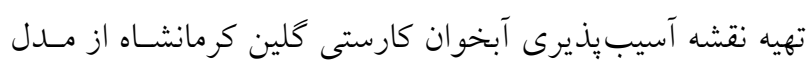

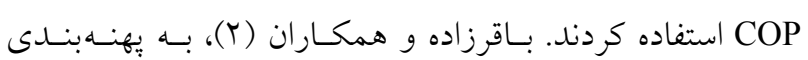




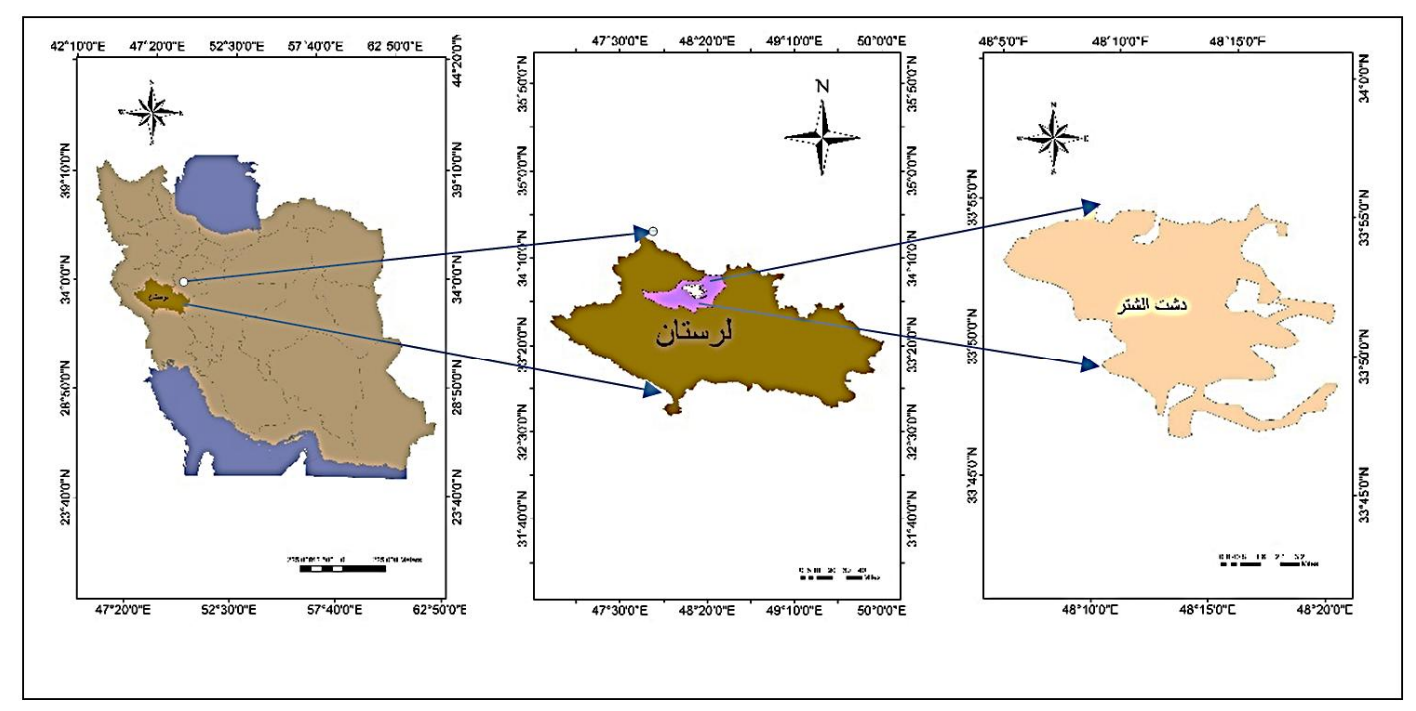

شكل 1. موقعيت منطقه مورد مطالعه

در نهايت در صورت مناسب بودن شرايط، به ايجـاد غارهـاى

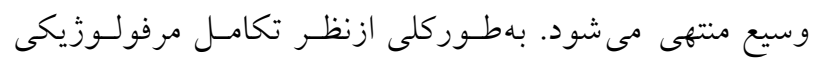

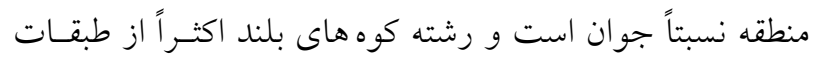

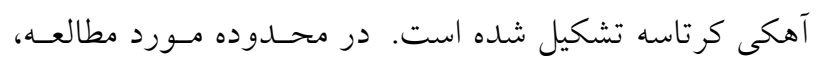

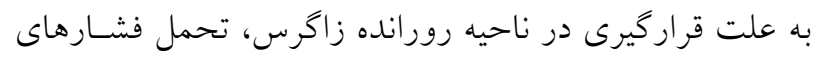

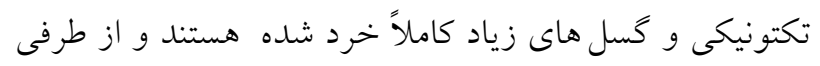

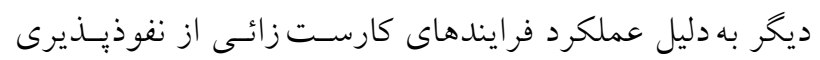

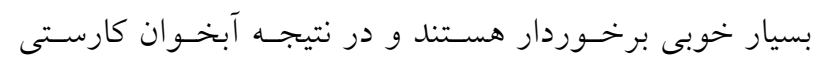

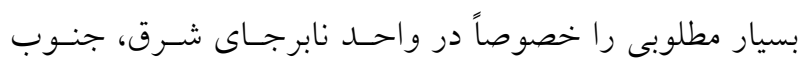

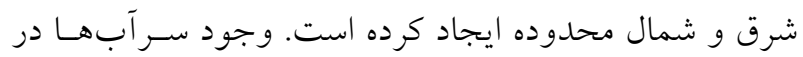

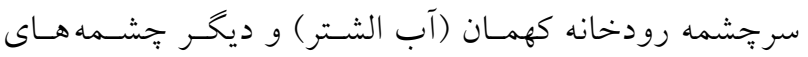

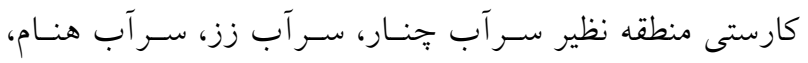

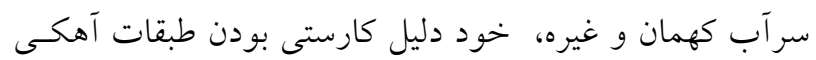

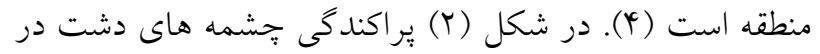
نقشه تويو گر افى نشان داده شده است.

\section{بم} درروش COP آسيب پِيذيرى بهعنوان برايندى از سه عامل O،C و

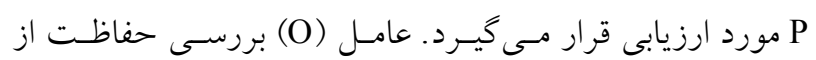

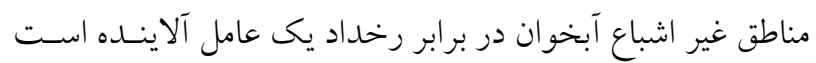

احاطه شده است. تشكيلات زمين شناسى اين منطقه متعلق بـه

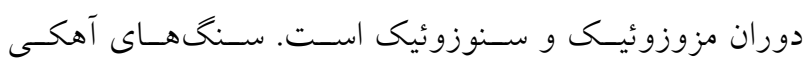

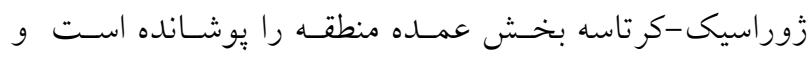

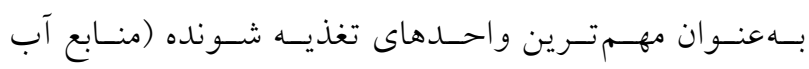

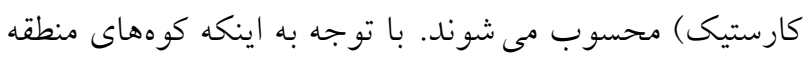

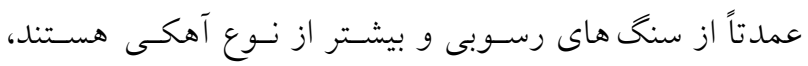

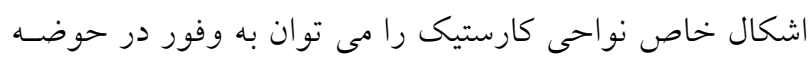

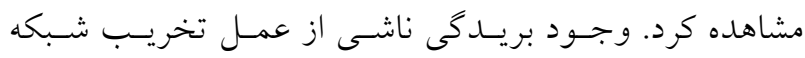

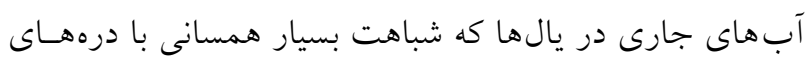

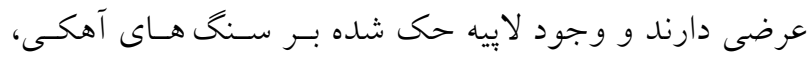

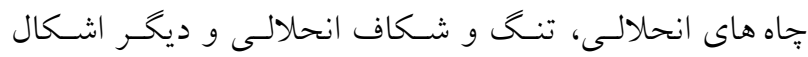

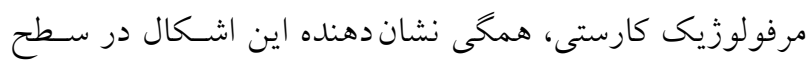

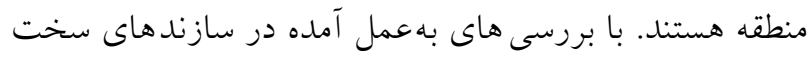
منطقه بهخصوص سازندهاى كربناته، علاوهبر تركيب شيميايى، جنس، تراكم، لايه بندى، شرايط رسوب كـــارى و نظـاير آن از

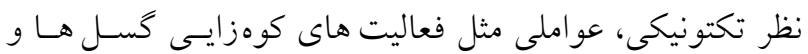

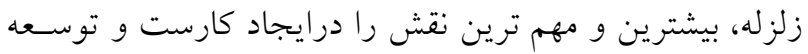

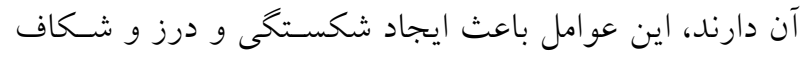

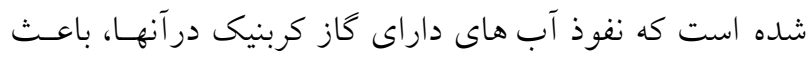

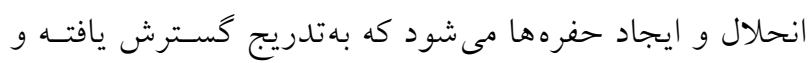




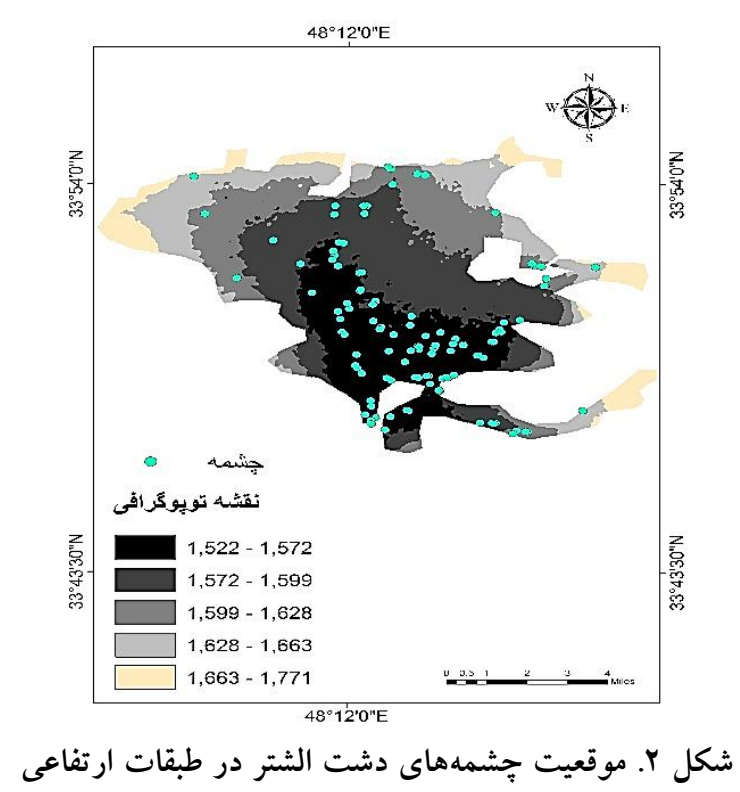

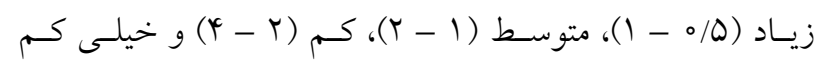
(1Q - (10)

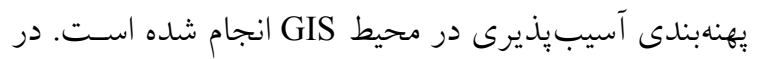

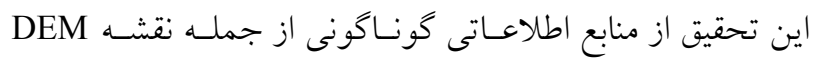

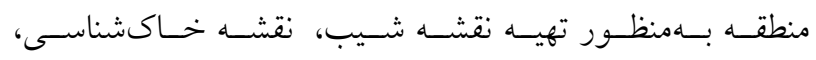

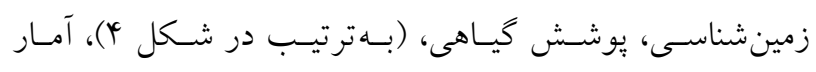

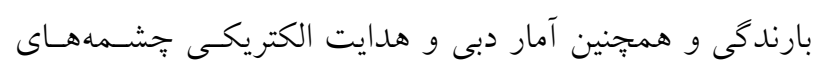
دشت الشتر جهت صحتسنجى نقشه نهايى استفاده شد.

\section{تهيه لايههاى روش COP

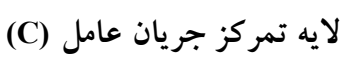

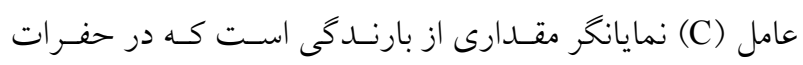

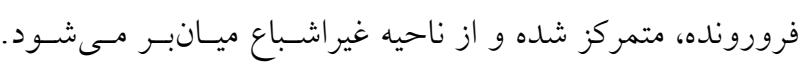

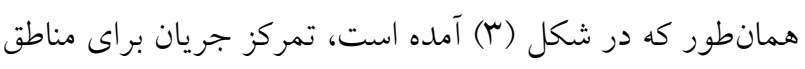

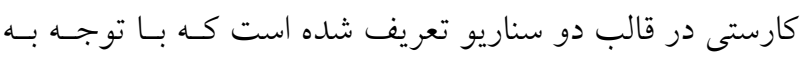

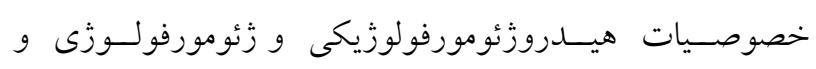

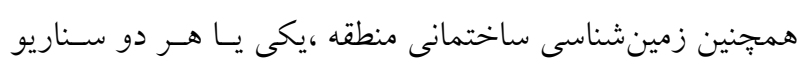

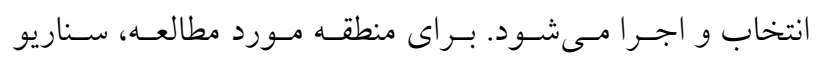

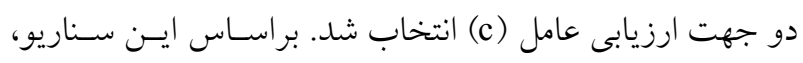

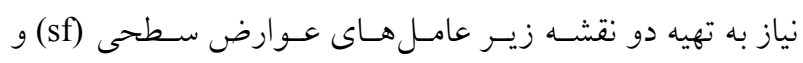

و عوامل P و C براى تصحيح درجه حفاظت (عامل O) استفاده

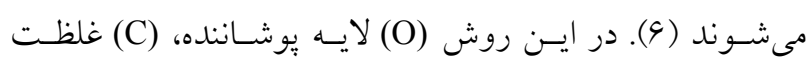

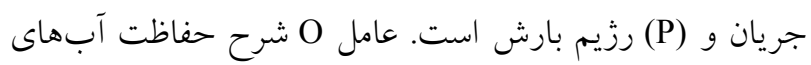
زيرزمينى توسط لايههاى بالاتر از منطقه اشباع شده است. عامـل

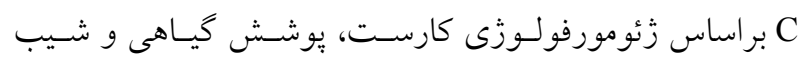

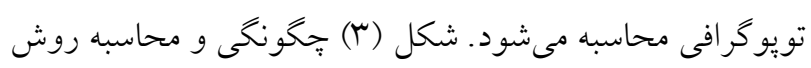

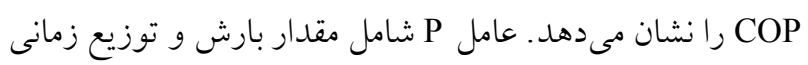

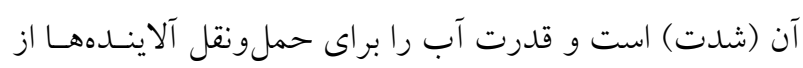

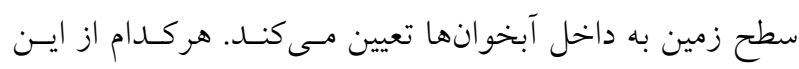

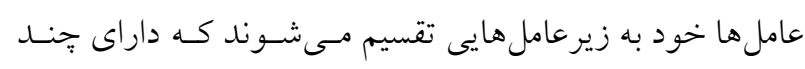

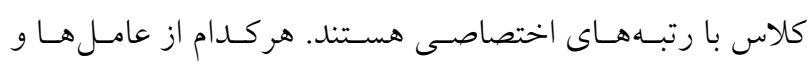
زيرعامل هايشان در محيط GIS تهيه مىشوند.

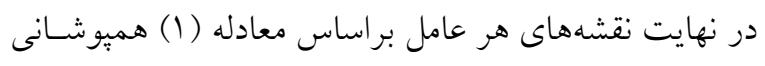

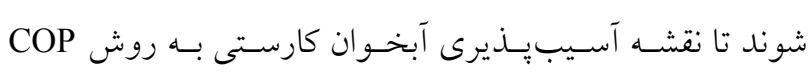
حاصل شود:

COP Index $=$ C . O . P

در اين رابطه C: تمركز جريـان، O: لايسه يوششى و P: بـارش

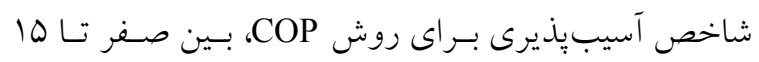

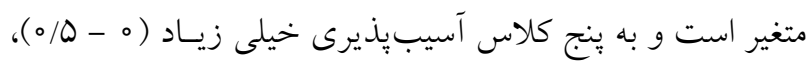




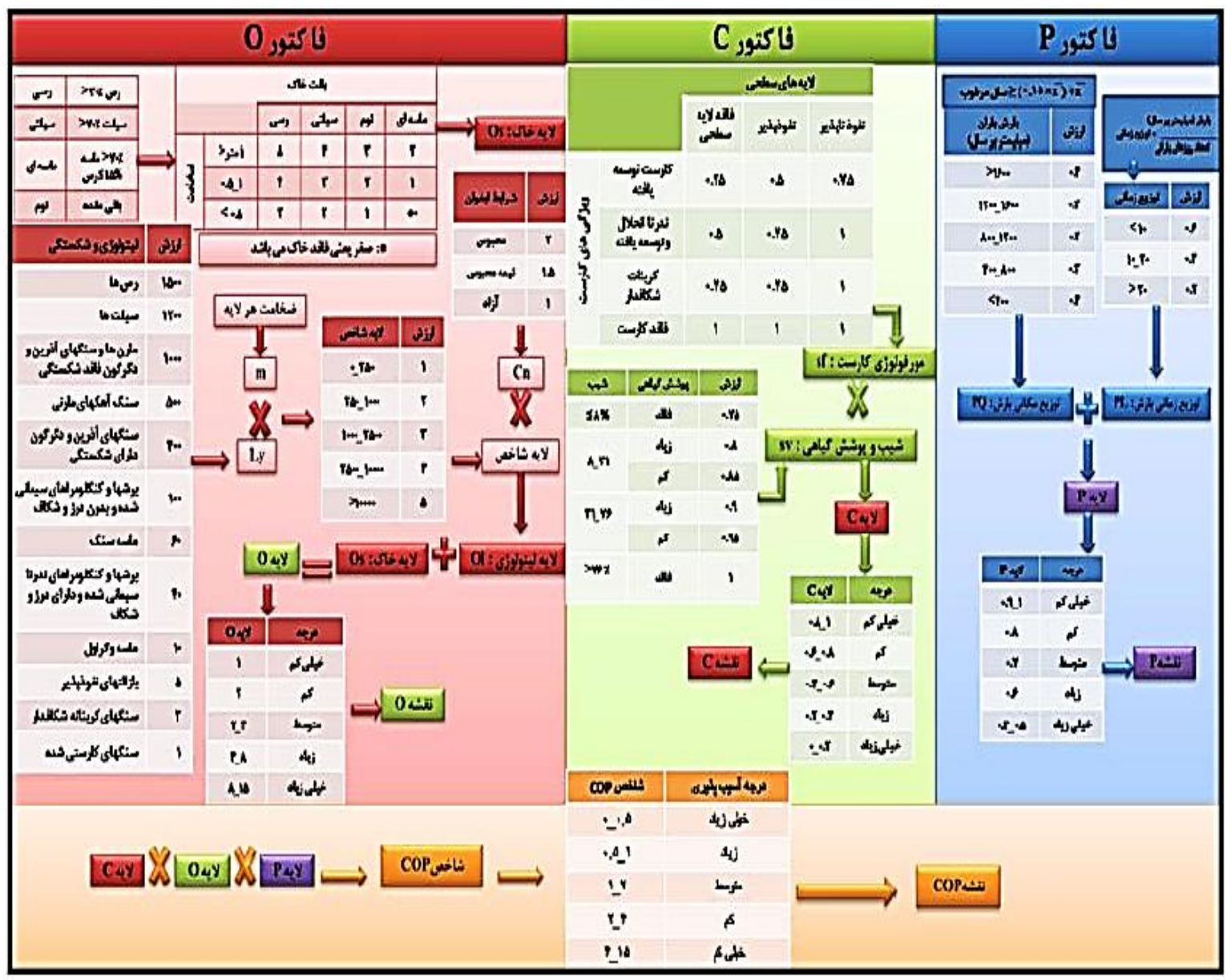

شكل r. نحوه محاسبه فاكتورهاى به كار رفته درروش Vias et al., Y०० ) COP

با توجه به شكل (ه)، نــواحى كـه بـا رنــ توسـى و قرمـز

مشخص شدهاند، نشاندهنده تأثير بيشتر عامل (C) هستند و بــه

اين معنى است كه حفاظت آبخوان كارستى كمتر مىشود كـه بـا توجه به نقشه زمينشناسى اين نواحى منطبق با مناطق با سـازند

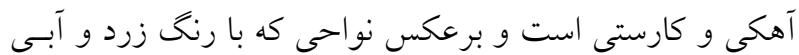
مشخصشدهاند، نشاندهنده تأثير كمتـر عامـل (C) هسـتند و در نتيجه حفاظت آبخوان كارستى بيشتر مىشود.

$$
\text { لايه هاى بوششى (عامل O) }
$$

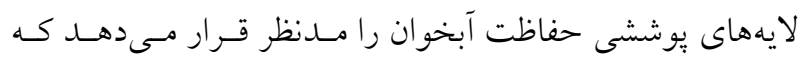

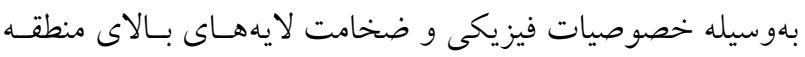
غيراشباع مشخص مى شود. در روش COP فقط دو لايه با نقـش هيدروزئولوزيكى مهم بهمنظور ارزيابى عامل (O) در نظر گرفتـه
شيب - يوشش كياهى (sv) است تا نقشه نهـايى عامـل C تهيـه شود. عوارض سطحى (sf): يار امتر عوارض سطحى آن دسـته از اشكال زئومورفولوزيكى مختص به سنخهاى كربناته و حضـور يا فقدان هر گونه لايه يوشانندهاى (نفوذيذير يـا نفوذنايـذير) كـهـ تعيين كنده اهميت فرايندهاى رواناب و يا نقوذ اسـت را در نظـر

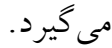
الف- شيب - يوشش كياهى: براى تهيه نقشه شيب - بوشش كياهى ابتدا نقشه شيب منطقه تهيه شد. نقشه بوشش گياهى نيـز

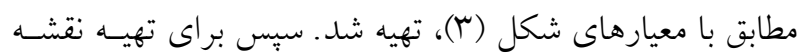
شيب - يوشش كياهى، دو نقشه شيب و نقشـه يوشـش كيـاهى باهم تركيب و ارزش گذارى شدند. درنهايت نقشههاى عـوارض سطحى و شيب - يوشش گياهى هميوشانى و كلاسبندى شدند و نقشه تمركز جريان حاصل شد (شكل ه). 


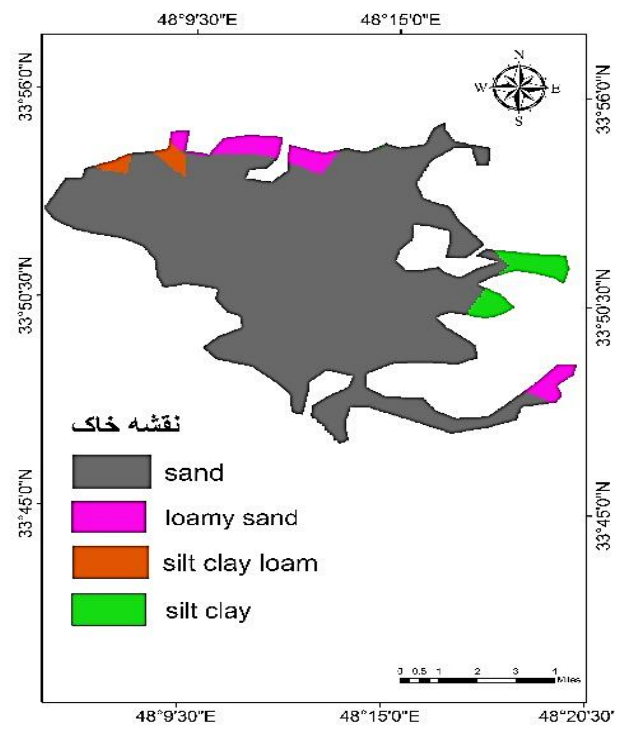

(ب)

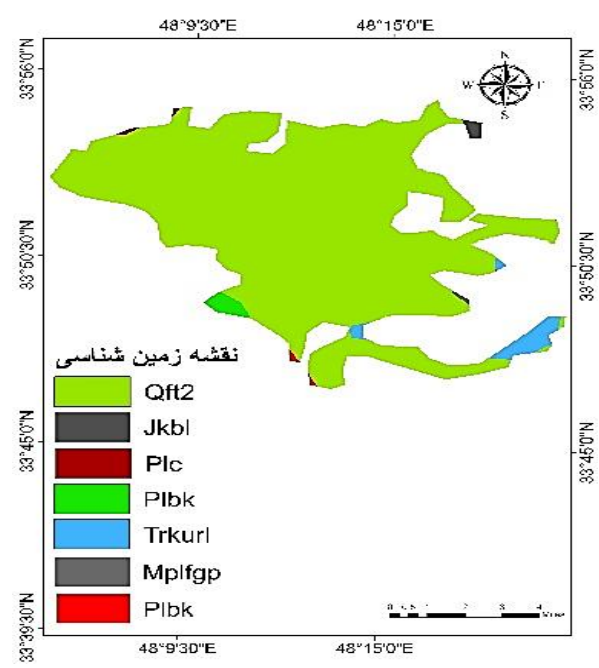

(2)

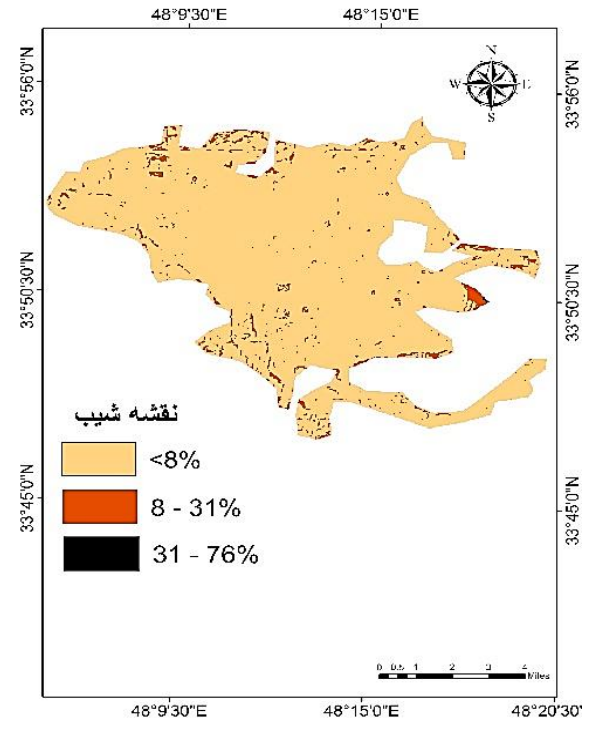

(الف)

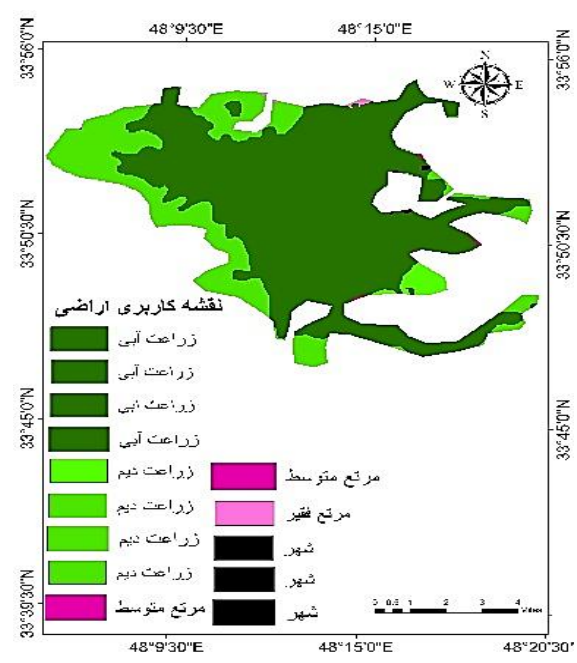

(ج)

شكل F. الف) نقشه خاك، ب) نقشه شيب، ج) نقشه كاربرى اراضى و د) نقشه زمينشناسى دشت الشتر

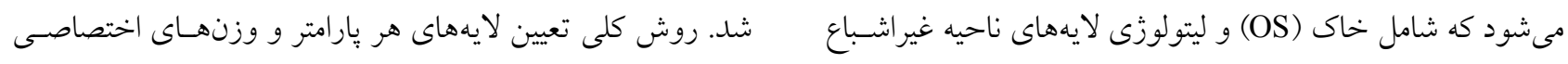

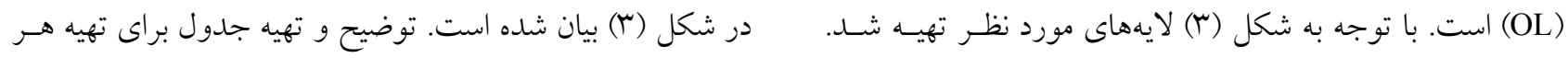

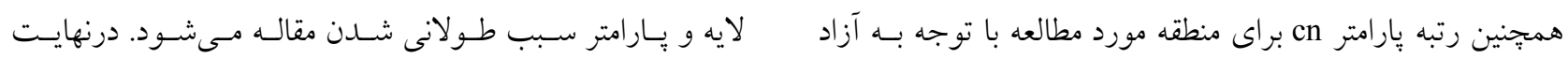

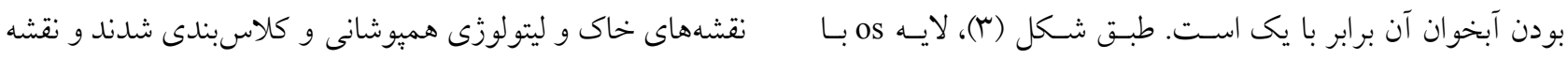

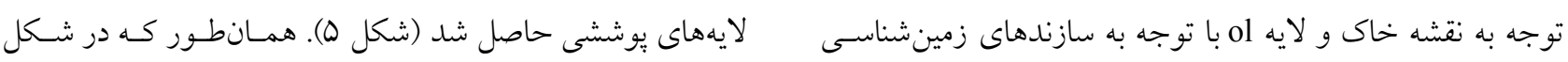

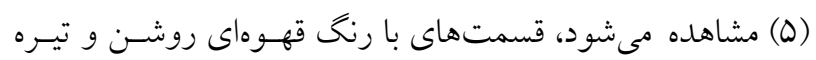

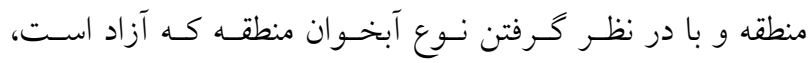

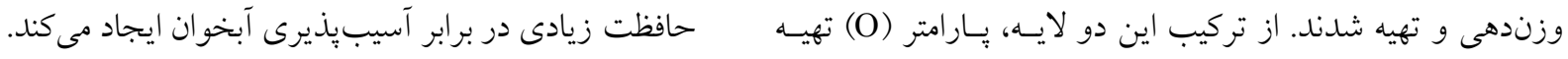



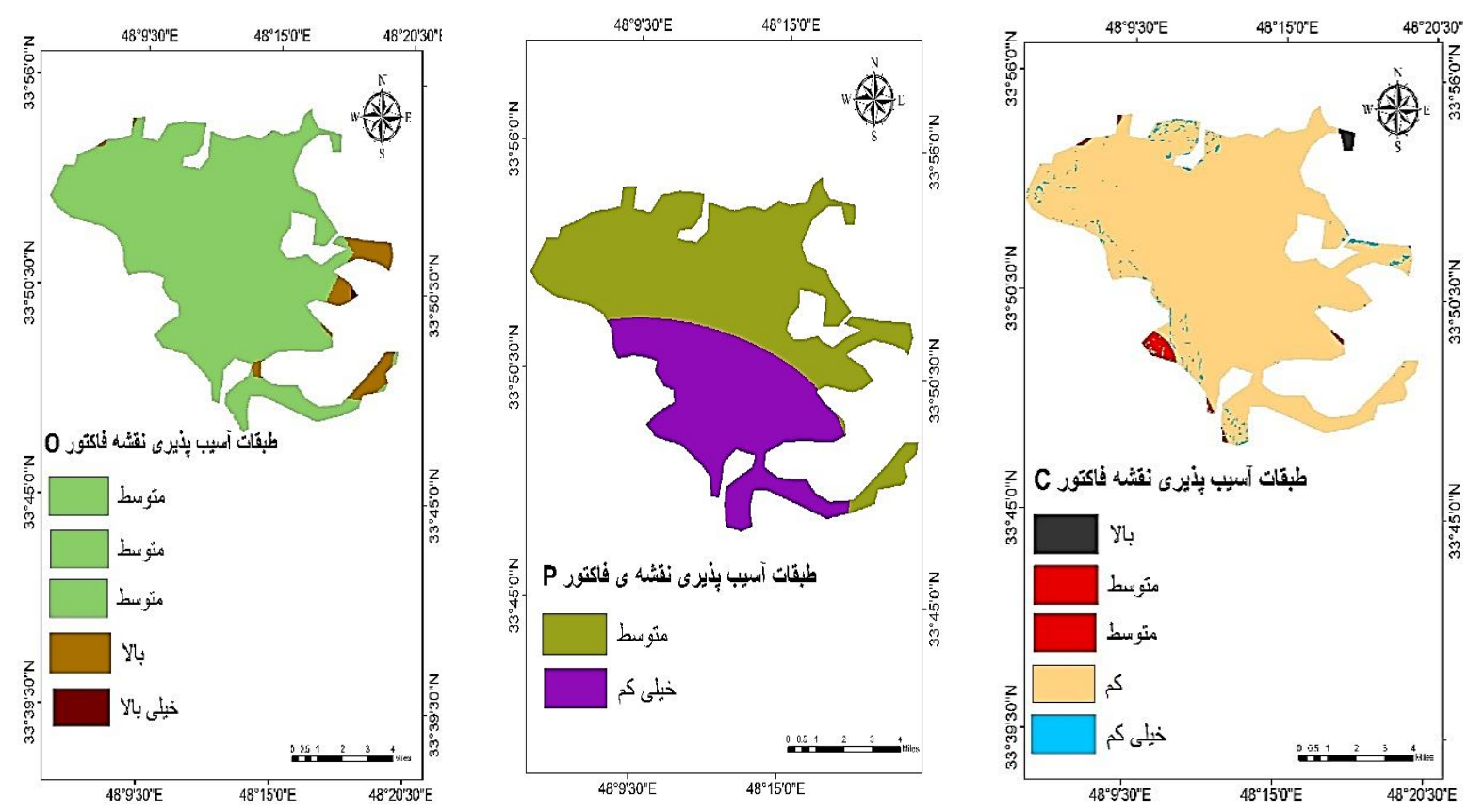

شكل ه. الف)نقشه تمركز جريان (عامل C)، ب) نقشه لايه بارش (عامل P) و ج) نقشه آسيب يذيرى نقشه فاكتور(O)

شد و بعد از تهيه بانك اطلاعـاتى در محسيط اكسـل، بـه فرمـت

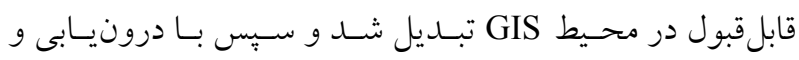

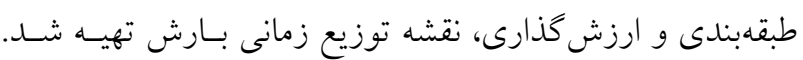

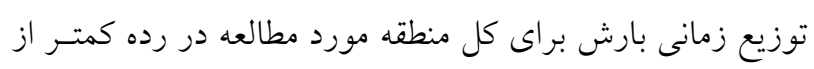

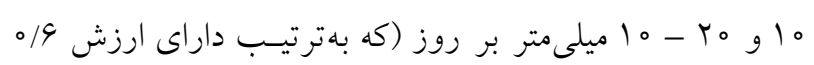

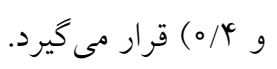
$\mathrm{PI}=\frac{\mathrm{P}}{\mathrm{N}^{\circ}}$

در اين رابطه P: ميانخين بارش سالانه (ميلى متر بـر سـال) و N:

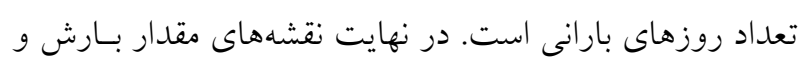

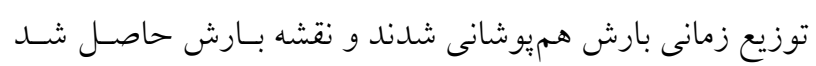

\section{نتايج و بحث}

$$
\text { نقشه آسيبِيذيرى COP وشت بحت الشتر }
$$

جهت محاسبه انديس نهايى COP از معادله ( ) استفاده شد كـه

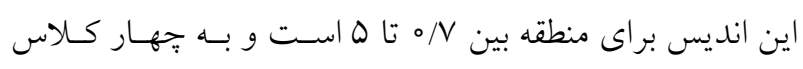

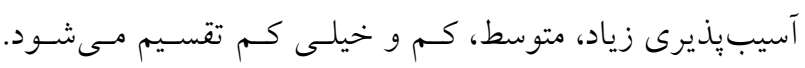

(P) الايه بارش بر طبق نظر ديلى و همكاران (V) عامل P) شامل مقدار بـارش و

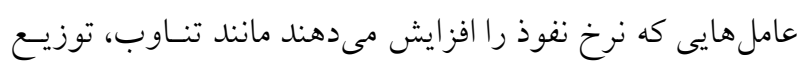

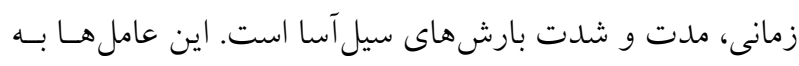

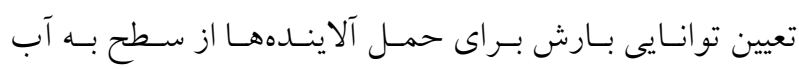

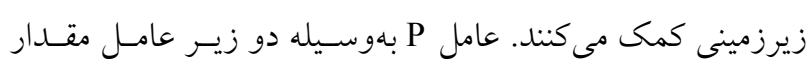

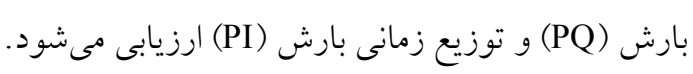

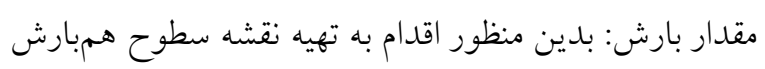

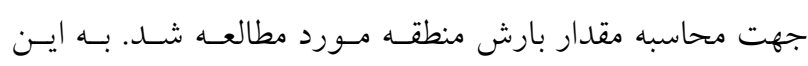

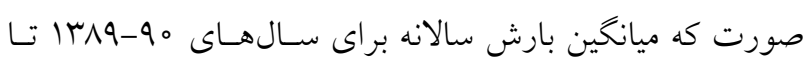

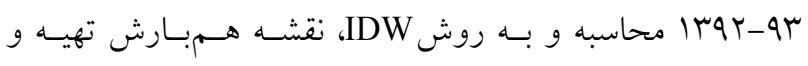

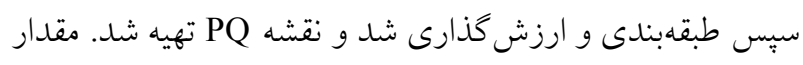

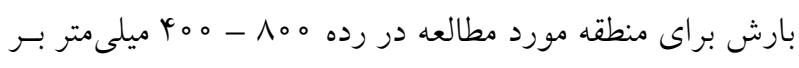

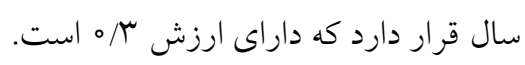

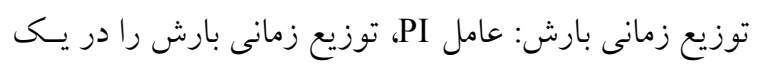

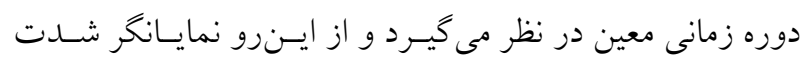

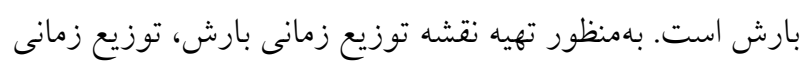

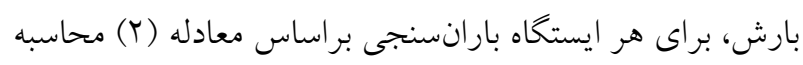




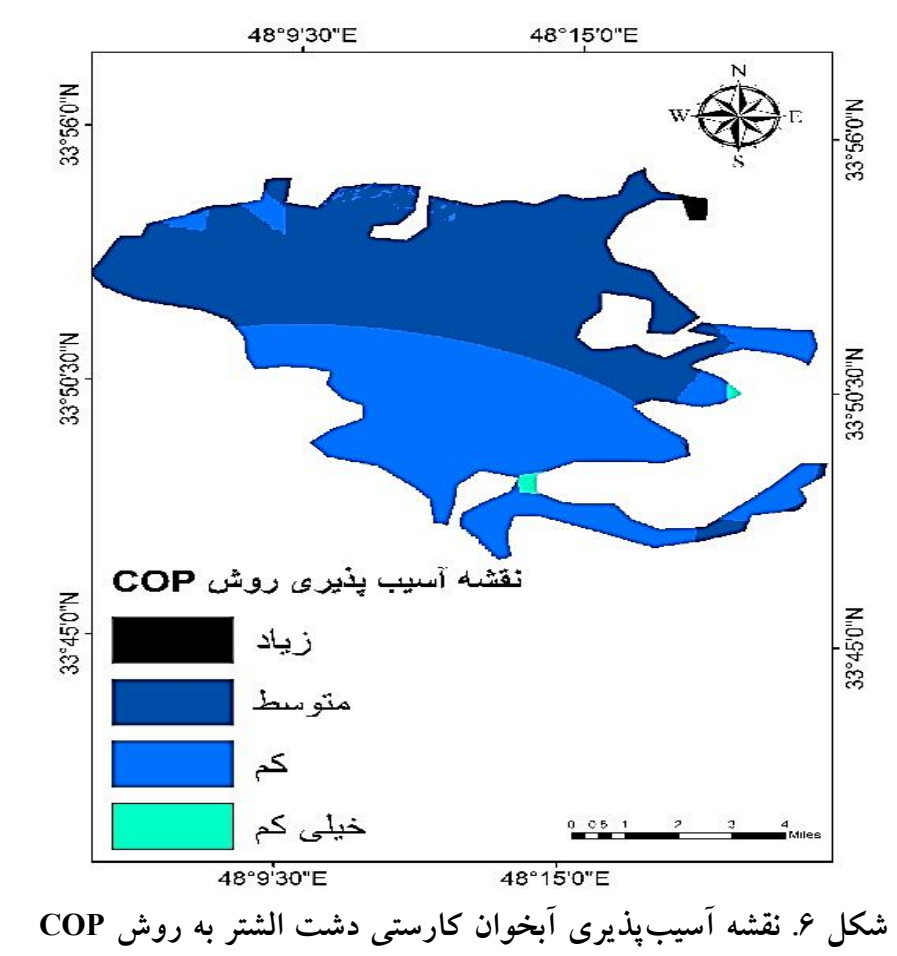

همكاران (11) بيان كردند كه زمان عبور آب از سطح به زيرزمين در آبخو انهاى كارستى، در نتيجه توسعه زهكشى كارستى كوتاه

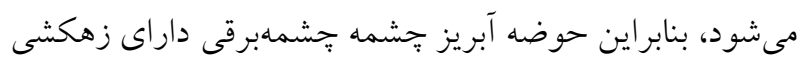

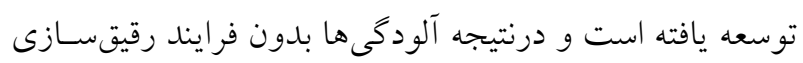

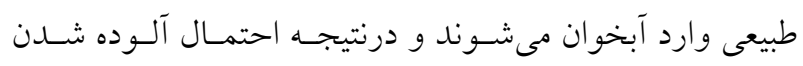

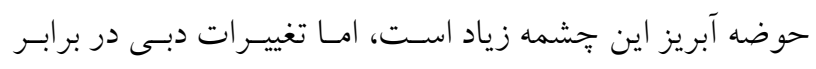

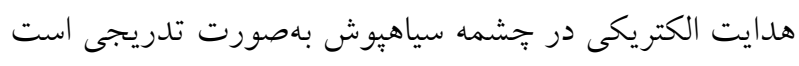

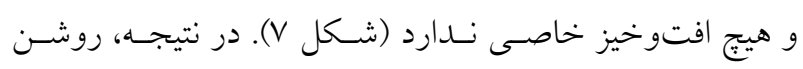

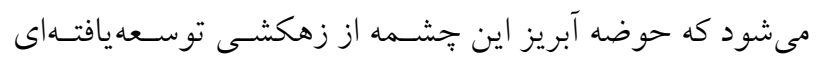

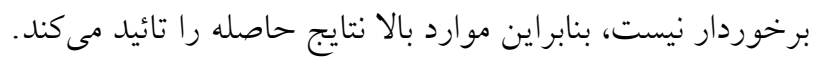

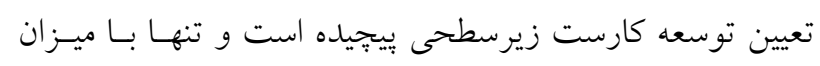

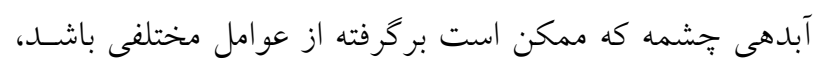
قابل تعيين نيست.

نتايج آناليز حساسيت (به روش حذف نقشه)

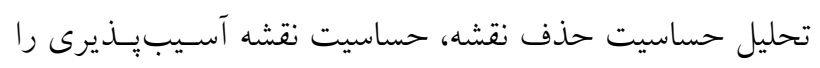

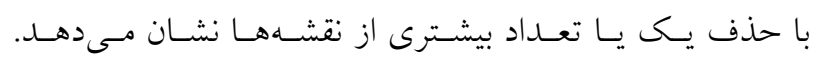
حساسيت حذف نقشه با استفاده از معادله (r) محاسبه مى شــود.
شكل (9) نقشه آسيب پِيذيرى منطقه مورد مطالعه بـه روش COP را نشان مىدهد. براى صحتسنجى نتـايج روش COP از دادههـاى هـدايت

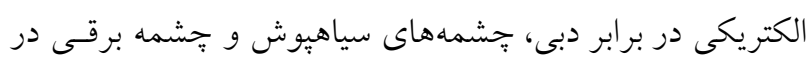

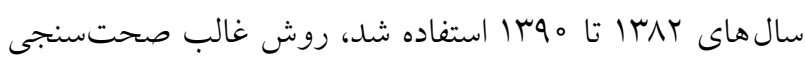

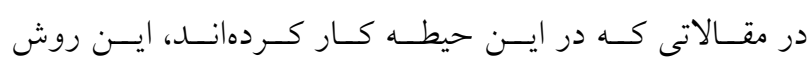
صحتسنجى است. از آنجايى كه هدايت الكتريكى در هـر ســال

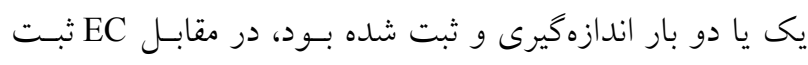
شده در هر ماه از هر سالى دبى ثبت شده در همان زمـان را نيـز

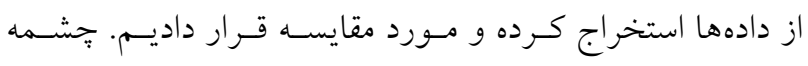
جشمهبرقى در محدودهاى از آبخوان دشت الشتر قـرار دارد كـهـ طبق نتايج داراى آسيب يذيرى متوسط است و جشمه سياهيوش

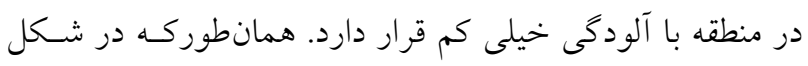

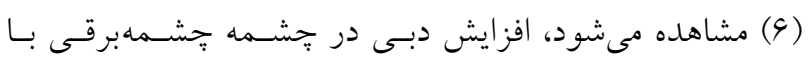

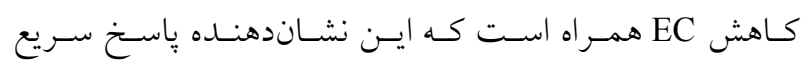

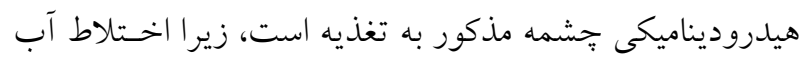

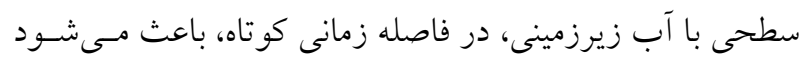

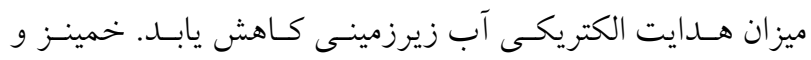




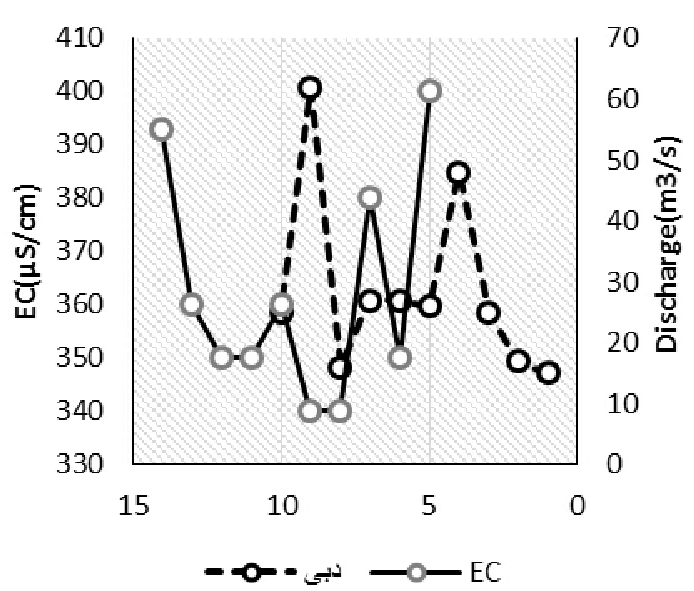

(ب)

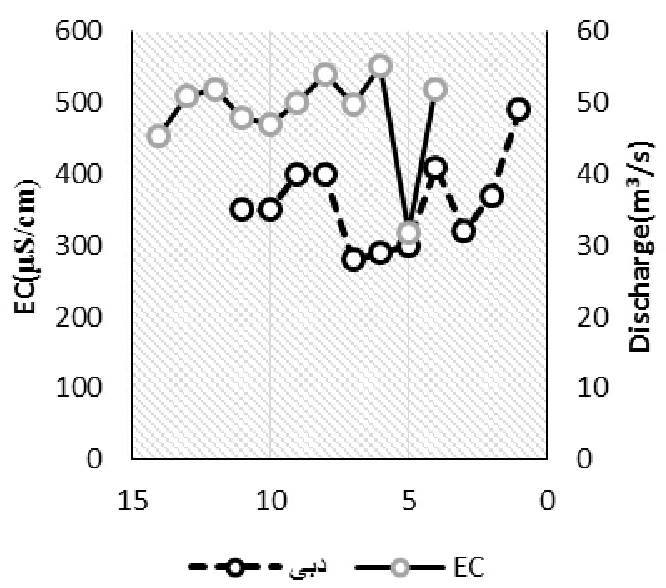

(الف)

شكل V. به ترتيب نمودار هدايت الكتريكى در برابر دبى جشمه الف) جشمه برقى و ب) سياهِيوش (ب)

\begin{tabular}{|c|c|c|c|c|}
\hline انحر اف معيار & كمينه & بيشينه & ميانگين & يارامتر حذف شده \\
\hline$V \circ / V V$ & rVo & $9 \mathrm{~V} 。$ & $r q v / 9$ & $\mathrm{C}$ \\
\hline$M q / \circ e^{r}$ & rᄉr。 & 109. & $V Q D 1 / 4$ & 0 \\
\hline$\Pi \Pi^{\prime} / \Delta$ 。 & $Y \circ \Delta_{0}$ & 9100 & WVQY/Q & $P$ \\
\hline
\end{tabular}

نتيجه گيرى $\quad S=\frac{\frac{D}{N}-\frac{D^{\prime}}{n}}{D}$

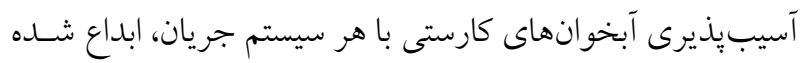

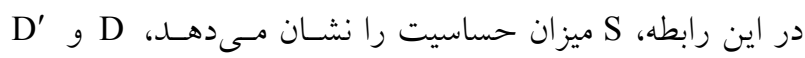

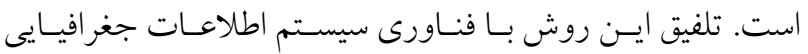

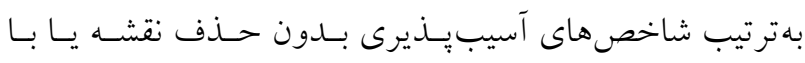

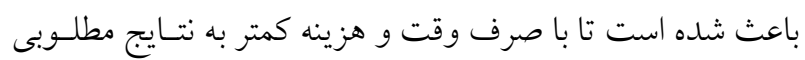

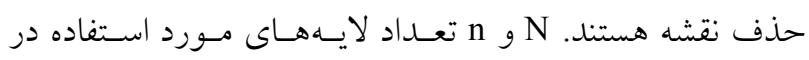

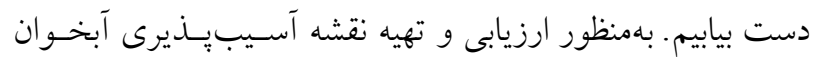

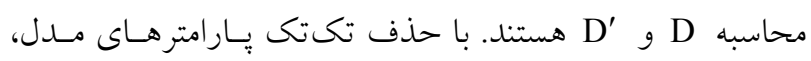

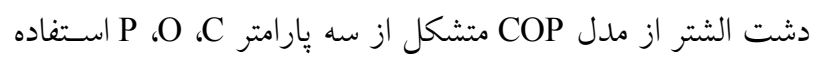
ميزان حساسيت نقشه نسبت به هر پارامتر بهدست آمـــ نتـايج

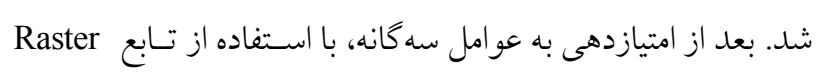

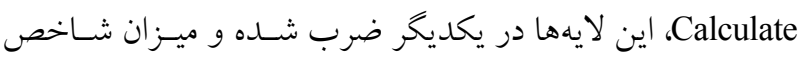

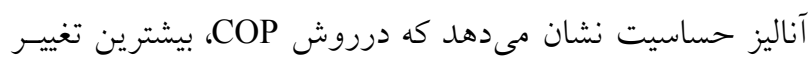

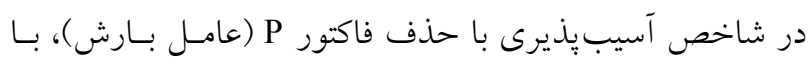

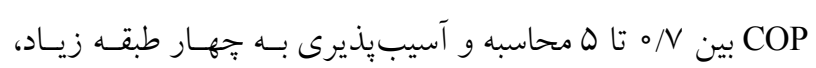

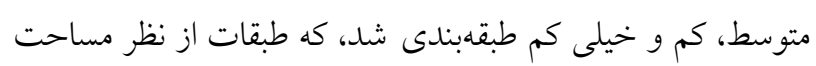

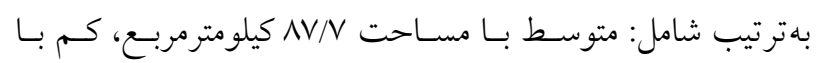

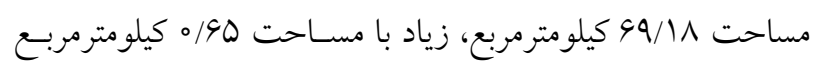

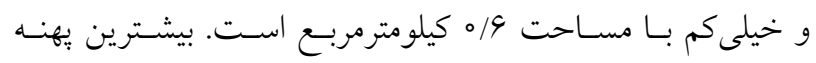
ميانخين تغييرات VV94/9 اتفاق مى افتلد و فاكتور C كمترين تأثير

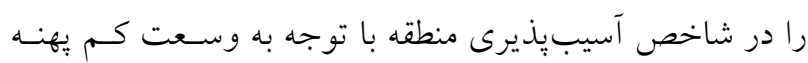

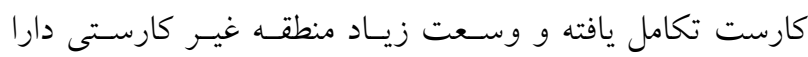
است. نتايج آمارى، حساسيت حذف نقشه در جدول (1) نشانس ونسان 


$$
\begin{aligned}
& \text { در ميزان آسيبِيذيرى داراست كه در مناطق با يهنسه كـم كارسـت } \\
& \text { مربسوط بــه طبقـهـ متوســط و سـيس كـم اسـت كـه طبـق نقشـهـ } \\
& \text { تكامل يافته اين امر طبيعى بهنظر مىرسد. نقشه عامل (O) حساكى } \\
& \text { زمينشناسى منطبق با سازند آبرفتى (Qft2) هستند و طبقه زياد كه }
\end{aligned}
$$

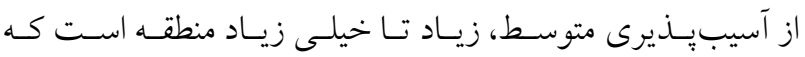

$$
\begin{aligned}
& \text { مساحت كمى در قسمت شمال شرقى دشت را به خود اختصاص } \\
& \text { نشاندهنده گسترش سازندهاى نفوذيذير آهكى، ماسهاى - كراولى ئى زئل }
\end{aligned}
$$

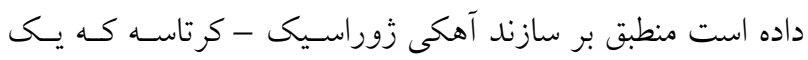

$$
\begin{aligned}
& \text { در منطقه است. در اين راستا اقدامات مديريتى نظير تعيسين حسريم } \\
& \text { منبع كارستى است، است. بررسى نقشه آسيبيذيرى بهدست آمده } \\
& \text { نواحى كارستى تكامليافته داراى سيستم زهكشى براى جلو گيرى }
\end{aligned}
$$

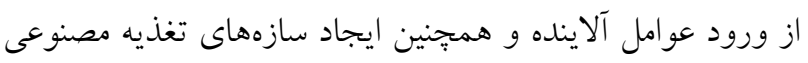

$$
\begin{aligned}
& \text { با آب باران، در نواحى مذكور بيشنهاد مىشود. } \\
& \text { نشان مىدهد كه عامل (C) بهعلت وسعت كم بهنه كارست تكامل } \\
& \text { يافته، وسعت زياد مناطق غير كارست، نقش اصلى را در كم بـودن } \\
& \text { ميزان آسيبِّيرى منطقه دارا است. فاكتور (P) بيشترين نقـش را }
\end{aligned}
$$

\section{منابع مورد استفاده}

$$
\begin{aligned}
& \text { ا. اسدى، م. ن. بقايىنزاد، ش. غلاميور وع. بهشتى قله زو. عqبا. تهيه نقشه آسيبذيذيرى آلودگى آبخوان بقيع خراسان رضوى به دو }
\end{aligned}
$$

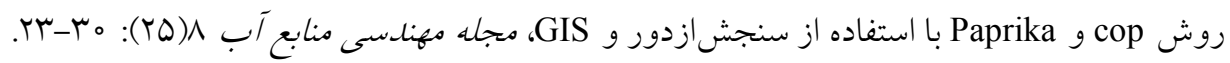

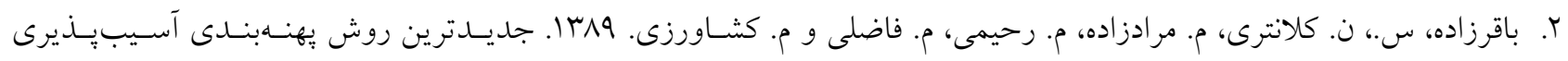

$$
\begin{aligned}
& \text { آبخوانهاى كارستى با استفاده ازتكنيك هاى GIS و سنجشازدور: روش COP (مطالعه موردى آبخوان كارستى شيمبا)، همـايش } \\
& \text { ملى زُئوماتيك، تهران. }
\end{aligned}
$$

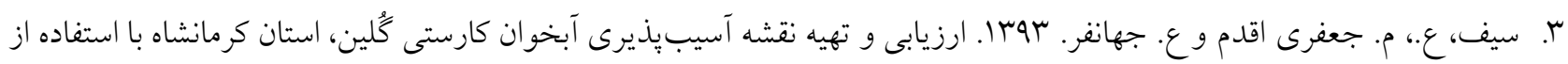

$$
\text { مدل COP، ثخروهش هاى ثئومورفولوزى كمى س(ب): }
$$

†. شركت سهامى آب منطقهاى لرستان. اوها|، گزارش توجيهى تخصيص منابع آب محدوده مطالعاتى الشتر. لرستان.

5. Adams, B. and S. S. D. Foster. 1992. Land-surface zoning for groundwater protection. Journal of the Institution of Water and Environmental Management 6: 312-3.

6. Andreo, B., N. Goldscheider, I. Vadillo, J. Mar Vias, C. Neukum, M. Sinreich, P. Jime'nez, J. Brechenmacher, F. Carrasco, H. Hotzl, M. JesuPerles and F. Zwahlen. 2006. Karst groundwater protection: First application of a Pan-European Approach to vulnerability, hazard and risk mapping in theSierra de L1'bar (Southern Spain), Science of the Total Environment 357: 54- 73.

7. Daly, D., A. Dassargues, D. Drew, S. Dunne, N. Goldscheider, S. Neale, C. Popescu and F. Zwhalen. 2002. Main concepts of the " European Approach" for (karst) groundwater vulnerability assessment and mapping. Hydrogeology Journal 10(2): 340-345

8. Dimitriou, E., I. Karaouzas, K. Sarantakos, I. Zacharias, K. Bogdanos and A. Diapoulis. 2008. Groundwater risk assessment at a heavily industrialised catchment and the impacts on a peri- urban wetland, Journal of Environmental Management 88(3): 526-538.

9. Doummar, J., A. Margane, T. Geyer and M. Sauter. 2012. Vulnerability Mapping Using the COP and EPIK Methods, Republic of Lebanon Council for Development and Reconstruction CDR Beirut, FEDERAL Republic of Germany Federal Institute for Geosciences and Natural Resources BGR Hannover.

10. Ducci, D. 2007. Intrinsic vulnerability of the Alburni karst system (southern Italy). Geological Society of London 279(1): 137-151.

11. Jim'enez, P., B. Andreo and F. Carrasco. 2004. An'alisis de la descarga del sector nororiental de la Unidad Hidrogeol'ogica de L'ibar (Provincias de M'alaga y C'adiz, Sur de Espa na) [Analysis of the discharge in the NE sector of Sierra de Libar hydrogeological unit (Provinces of Malaga and Cadiz, S Spain). In: Proceeding of the Portuguese-Spanish Congress on Groundwater in the South of Iberian Peninsula], Faro, Portugal. PP: 106-117.

12. Kattaa, B., W. Al-Fares and A. Al Charideh. 2010. Groundwater vulnerability assessment for the Banyas Catchment of the Syrian coastal area using GIS and the RISKE method, Journal of Environmental Management 91: 1103-1110.

13. Leyland, R. 2008. Vulnerability mapping in karst terrains, exemplified in the widercradle of humankind world 
heritage site, MSc. Thesis. Sciencia (Environmental and Engineering Geology) in the Department of Geology, Faculty of Natural and Agricultural Sciences, University of Pretoria, South Africa.

14. Mudarra, M. and B. Andreo. 2011. Relative importance of the saturated and the unsaturated zones in the hydrogeological functioning of karst aquifers, The case of Alta Cadena (Southern Spain), Journal of Hydrology 397: 263-280.

15. Nasseery, H. R. and F.Saremi Nej jad. 2012. Comparing vulnerability delineativ ve of aquifer using DRASTIC and fuzzy logic methods (case study: Gulgir plain of Masjed Solieman, Iran), In: Proceeding of the GIS Ostrava 2012 Conference. Czech Republic.

16. Plan, L., K. Decker, R. Faber, M. Wagreich and B. Grasemann. 2009. Karst morphology and groundwater vulnerability of high alpine karst plateaus, Environmental Geology 58(2): 285-297.

17. Ravbar, N. 2007. The Protection of Karst Waters, a Comprehensive Slovene Approach to Vulnerability and Contamination Risk Mapping, ZRC Publishing Ljubljana.

18. Vias, J. M., B. Andreo, M. J. Perles, F. Carrasco, I. Vadillo and P. Jim'enez. 2006. Proposed method for groundwater vulnerability mapping in carbonate (karstic) aquifers: the cop method: application in two pilot sites in southern spain, Hydrology Journal 14(6): 1-14

19. . Vrba, J. and A. Zaporozec. 1994. Guidebook on Mapping Groundwater Vulnerability. International Association of Hydrogeologists, Verlag, Heinz Heise. 


\title{
Evaluation and Sensitivity Analysis of COP Method Based on the RS and GIS Techniques to Determine Aquifer Vulnerability of Aleshtar Karst Plain in Lorestan Province
}

\author{
H. Yousefi ${ }^{1 *}$, A. Haghizadeh², Y. Yarahmadi ${ }^{1}$ and P. Normohammadi ${ }^{2}$
}

(Received: February 7-2017 ; Accepted: November 14-2017)

\begin{abstract}
To determine the potential for groundwater contamination, vulnerability should be evaluated in different areas susceptible to contamination should be investigated. Aquifer (carbonate) karst or part of it is karst aquifer in the western region of Iran; due to the natural conditions of the region and human activities, they are susceptible to contamination by carbonate aquifer through holes devourer and feeding point leading to pollution. The aim of this study was to analyze aquifer vulnerability zoning map karst plain elster by using COP. This model uses three parameters including lining (O) the concentra flow $(\mathrm{C})$ and precipitation regime $(\mathrm{P})$ to assess the vulnerability of groundwater against pollution GIS software. The results showed that the plain with an area $7.8 \mathrm{~km}^{2}$ was dominated in terms of vulnerability, being in the middle class. Other classes, respectively, were low with the area $18.69 \mathrm{~km}^{2}$, high with the area $0.65 \mathrm{~km}^{2}$ as part of the northeast plain, and much less with the area of $0.6 \mathrm{~km}^{2}$, The results of the sensitivity analysis also showed that at the factorization $(\mathrm{P})$ due to appropriate rainfall area, the maximum impact was in determining the vulnerability of the area. And the factor (C) minimum has impact on determining the vulnerability of the area. Due to the small size of the mature karst area, the wide extent of non-karst region was shown for the verification of results related to electrical conductivity data (EC) against discharge wells in the region with the high vulnerability and moderate. A comparison was made too.
\end{abstract}

Keywords: Vulnerability, COP method, GIS, Aleshtar karst Aquifer

1. Department of Renewable Energies and Environment, Faculty of New Sciences and Technologies, University of Tehran, Tehran, Iran.

2. Department of Rangeland and Watershed Management, Faculty of Agriculture and Natural Resources, University of Lorestan, Khoram Abad, Iran.

*: Corresponding Author, Email: Hosseinyousefi@ut.ac.ir 